\title{
THE BANKING SECTOR IN CHINA IN THE LIGHT OF THE CONTEMPORARY FINANCIAL CRISIS
}

\author{
Pawel Mrowiec
}

\section{Key words:}

financial crisis, banking sector, China

\begin{abstract}
The scale of the impact of the contemporary "American crisis" is undoubtedly global. Many experts believe that the crisis began with the bankruptcy of the 158-year-old investment bank "Lehman Brothers", which was announced on 15 September 2008, although the problems of American investment banks began a few months earlier when "Bear Stearns" was acquired by "JPMorgan Chase", and "Merrill Lynch" was taken over by "Bank of America". The crisis in the U.S. subprime mortgage market has brought into the most serious collapse of global economic activity since so-called "Great Depression" of the 30s of the last century. Today's "American crisis" is described in numerous publications and reports diagnosing its causes, as well as consequences for American and European banking sector and further prospects for development of modern economies in the world. However, while "American crisis" caused serious turmoil in the United States and Europe, one can say that the economy and banking system in China has demonstrated exceptional resistance to its effects. This finding indicates the need to analyze and try to assess the functioning of modern banking sector in China, which has been undertaken in this article.
\end{abstract}

\section{Introduction}

The phenomenon of the financial crisis is widely described in scientific studies, which confirms the importance of that phenomenon in modern economy ${ }^{1}$. In 2009 it was indicated that the modern banking sector faces great challenges concerned with adapting itself to dangers resulting from the universality of "global" financial instruments as well as the globalization of the capital market ${ }^{2}$. Despite the opinion common at that time that the powerful decline in Chinese economy export would cause its inclusion under the influence of the crisis on a scale comparable to American and European economy, nothing like that happened. The conclusion is that these economies despite strong relations are characterized by some independence. This confirms the validity of the thesis regarding the phenomenon of decoupling in the global economy i.e. gaining independence from the situation of EuroAtlantic area economies. According to economic experts and politicians (such as former Secretary of Treasury Lawrence Summers, who evaluated the phenomenon, using aviation terminology), global economy consists of two engines (twin engines) that may be the U.S. economy and China economy ${ }^{3}$. Therefore, it is worth to carry out an analysis of the Chinese economy as well as the banking sector functioning within that economy. Besides the perceived relationships can be useful in diagnosing the causes of the crisis and measures that can be taken to prevent it, also in countries particularly affected by the crisis.

\footnotetext{
${ }^{1}$ More information in: Krugman, P. Wracaja problemy kryzysu gospodarczego.Warszawa:PWN, 2001; Morawski, W. Kronika kryzysów gospodarczych. Warszawa:Wydawnictwo Trio, 2003.

${ }^{2}$ Mrowiec, P.O niektórych skutkach kryzysu finansowego dla systemu bankowego. In: Bankowość w dobie kryzysu finansowego a perspektywy rozwoju regionów, T. 1:Banki wobec kryzysu finansowego.Bielsko Biała:Wyższa Szkoła Bankowości i Finansów, 2009.

${ }^{3}$ Haliżak, E. Chiny a współczesny kryzys finansowy i gospodarczy, p. 47.In Osiński,J. (ed.)Państwa narodowe wobec kryzysu ekonomicznego.Warszawa:Oficyna Wydawnicza SGH , 2010.
} 


\section{The Directions of change and current economic indicators in China}

China's economy is the third - after economies of the United States and Japan - world economy, whose GDP in 2010 exceeded 5.8 billion USD, while at the same time China is the world's greatest exporter of goods. The growth of China's economy is related to the development of private entrepreneurship, which was launched in 1978 as a result of the liberalization of the Chinese market.

China has the world's largest foreign exchange reserves, which in 2011 exceeded 3.200 billion USD. The substantial part of Chinese reserves is invested in American securities ${ }^{4}$.

According to official statistics the Chinese private sector produces about sixty-five percent of GDP, bringing also two thirds of all tax revenues to the state budget. The World Bank's database indicates an increase in the number of enterprises in China in recent years. The number of private companies operating in the domestic market, despite the crisis on financial markets, increased from around 1.6 million to over 2 million, in the period between 2008 and 2010. There has also been an increase in the number of collective enterprises, while at the same time a decrease in the number of state enterprises has been noticed. Private companies are mainly small companies, retailing on a small scale ${ }^{5}$. The dynamic growth in the number of private enterprises has forced changes in the Chinese banking sector, resulting in adjusting the banks services portfolio to the needs of newly created companies ${ }^{6}$.

The present position of China in the global economy is a result of internal changes that have been carried out since 1979 (referred to as the four modernizations), and its opening for the world economy ${ }^{7}$. The economic potential of China on basis of selected macroeconomic indicators is presented in table 1.

Table 1. China's macroeconomic indicators in $2009-2011$.

\begin{tabular}{|l|r|r|r|}
\hline \multicolumn{1}{|c|}{ Indicators } & \multicolumn{2}{c|}{$\mathbf{2 0 0 9}$} & \multicolumn{1}{c|}{$\mathbf{2 0 1 0}$} \\
\hline Nominal GDP (In billions USD) & 4.814 & 5.745 & 6.989 \\
\hline Real GDP growth (\%) & 8,7 & 10,3 & 9,2 \\
\hline Unemployment rate (\%) & 4,3 & 6,1 & 6,5 \\
\hline Exports (in billions of USD) & 1.194 & 1.506 & 1.898 \\
\hline The growth rate of exports (\%) & $-16,8$ & 25 & 20,3 \\
\hline Import (in billions of USD) & 921,5 & 1.307 & 1.743 \\
\hline The rate of growth of imports (\%) & $-14,2$ & 30 & 24,9 \\
\hline Foreign debt & 347,1 & 548,9 & 697,2 \\
\hline Foreign exchange reserves and gold (U.S. \$ bn) & 2.206 & 2.622 & 3.236 \\
\hline
\end{tabular}

Source: National Statistical Office of the PRC, World Bank, Ministry of Commerce of the PRC, quoted after http://www.mg.gov.pl.

In the period after the full disclosure of the "American crisis" in the third quarter of 2008, China's GDP growth rates decreased to 8.7\% (2009), although the average annual real GDP growth rate in the last twenty years was $9.6 \%$ and was one of the fastest in the world (the average GDP growth in other countries at that time amounted to 3.1\%). However, from 2010

\footnotetext{
${ }^{4}$ http://www.mg.gov.pl

${ }^{5}$ http://www.psz.pl(27.12.2011): M. Młynarczyk, Chiny: bliżej kapitalizmu?

${ }^{6}$ More information about financial crisis in Gostomski, E. Bankowość międzynarodowa.Gdańsk:Wydawnictwo Uniwersytetu Gdańskiego, 2010.

${ }^{7}$ More information in: Grabke, K., Horvath, S., Scharinger, M., Wolf, J. China auf dem Weg zur Weltmacht?Wien:RSO, 2008; Fungacova, Z., Korhonen, I. Like China, the Chinese banking sector is in a class of its own. BOFIT Discussion Papers, 2011, No. 32.
} 
there was a return to the previous dynamic growth. E. Haliżak indicates that China seriously influenced by the financial crisis in East Asia in 1997/1998 - drew practical conclusions, taking actions securing them from the similar situation in future. There were following measures ${ }^{8}$ :

- supporting and sustaining (relatively high for those societies) the high savings rate and consequently the high investment rate,

- ensuring the budget stability,

- pursuing an export policy and accumulating currency reserves designed to protect against some turbulences in international finance, especially against an unexpected depreciation and speculative attacks on their currencies,

- postponing the introduction of liquid exchange rate and the practical application of various forms of state-controlled exchange rate regimes until further notice.

Maintaining the high rate of GDP growth in 2009-2011 was possible thanks to the relative stability of trade balance and stimulating domestic demand by a two-year anti-crisis package amounting to 586 billion USD.

Since 1978 foreign investments have contributed to the growth of efficiency of Chinese industry by about one-third. The dynamic development of private sector in China left its mark on the state sector. In 1998-2002 state-owned companies laid off about 21 million of workers. This is more than the total number of employees in the U.S. manufacturing industry 9

It is also well worth mentioning that China has the highest level of foreign exchange reserve and gold in the world, estimated on the level of more than 3.200 billion USD. Followed by Japan with 1.22 billion USD at the end of $2011^{10}$. In contrast, the data published by the NBP (the National Bank of Poland) indicate that at the end of May 2012 Polish foreign exchange reserves amounted to 98 billion $\mathrm{USD}^{11}$, which is more than 32 times less than China's foreign exchange resources.

The important factor in the development of the Chinese economy is also Confucianism as the main philosophy of life and authoritarism as the primary means of exercising state power. The values derived from the philosophy of Confucius, extremely important for the Chinese economy, are the following: the value of hard work, thrift, perseverance and above all loyalty ${ }^{12}$.

\section{The Analysis of functioning and directions of development of the banking sector in China}

In 1983 there were four specialized banks (so called the "Big Four", i.e. Industrial and Commercial Bank of China / ICBC /, China Construction Bank / CCB /, Bank of China / BOC / and Agricultural Bank of China / ABC /). At present we can speak of "Big Five" as

\footnotetext{
${ }^{8}$ Haliżak, E. Chiny a współczesny kryzys finansowy i gospodarczy, s. 48.In: J. Osiński (ed.)Państwa narodowe wobec kryzysu ekonomicznego. Warszawa:Oficyna Wydawnicza SGH , 2010.

${ }^{9}$ Pasek, D. Jak zawładnąć ekonomicznie światem w 30 lat -reformy zastosowane w Chinach i socjalizm z chińskimi cechami. In: Michalczyk, W. (ed.) Wybrane problemy gospodarki światowej pierwszej dekady nowego wieku. Wrocław: Wydawnictwo Uniwersytetu Ekonomicznego we Wrocławiu, 2009, s. 103.

${ }^{10} \mathrm{http}: / / \mathrm{www}$. iol.co.za

${ }^{11}$ http://www.nbp.pl

${ }^{12}$ More information in Pawłowski, J. Państwo we wczesnej filozofii konfucjańskiej. Warszawa, Wydawnictwo Uniwersytetu Warszawskiego, 2010.
} 
Bank of Communications has entered this group. The number of units and financial data of the "Big Five" are presented in table 2.

Table 2. The number of units and financial data of the "big five" in 2009.

\begin{tabular}{|l|r|r|r|r|r|}
\hline \multicolumn{1}{|c|}{ Bank Name } & $\begin{array}{c}\text { Number of } \\
\text { units }\end{array}$ & $\begin{array}{c}\text { Total assets } \\
\text { (U.S. \$ } \\
\text { billion) }\end{array}$ & $\begin{array}{l}\text { Loans } \\
\text { (U.S. \$ } \\
\text { billion) }\end{array}$ & $\begin{array}{c}\text { Deposits } \\
\text { (U.S. \$ } \\
\text { billion) }\end{array}$ & $\begin{array}{c}\text { Net profit } \\
\text { for 2009 } \\
\text { (U.S. \$ } \\
\text { billion) }\end{array}$ \\
\hline $\begin{array}{l}\text { Industrial and } \\
\text { Commercial Bank of } \\
\text { China }\end{array}$ & 16.232 & $1.726,5$ & 839,3 & $1.431,5$ & 19,0 \\
\hline $\begin{array}{l}\text { China Construction } \\
\text { Bank }\end{array}$ & 13.384 & $1.409,8$ & 706,1 & $1.172,2$ & 15,7 \\
\hline $\begin{array}{l}\text { Agricultural Bank of } \\
\text { China }\end{array}$ & 23.624 & $1.301,4$ & 606,2 & $1.098,5$ & 9,5 \\
\hline Bank of China & 9.988 & $1.282,2$ & 719,3 & 979,4 & 12,5 \\
\hline $\begin{array}{l}\text { Bank of } \\
\text { Communications }\end{array}$ & 2.761 & 484,8 & 269,4 & 347,5 & 9,8 \\
\hline Total & 65.989 & $6.204,7$ & $3.140,3$ & $5.029,1$ & 66,5 \\
\hline
\end{tabular}

Source: my own elaboration based on: Dabrowski, J., Geppert, A. Banking in China. Warsawa, Dabrowski Finance, 2011, p.3.

The largest bank, Industrial and Commercial Bank of China in 2009-2011 has increased the possessed total assets by 305.5 billion USD, simultaneously placing ninth on the list of world's largest banks in 2011. At the same time in the same ranking ICBC took the first place as the largest employer with over 390 thousand workers ${ }^{13}$. Overall, in the ranking of the 50 largest banks in the world are 6 Chinese banks with a balance total amount of more than 8.200billion USD, which represents $12 \%$ of bank assets included in the ranking. In contrast, the participation of Chinese banks in the 50 largest banks in 2010 was $10 \%$.

On the other hand, the balance total amount of the Polish banking sector at the end of the third quarter of 2011 amounted to over 1.280.401 million $\mathrm{zl}$ and financial result was almost 12 billion $\mathrm{zl}^{14}$.

The large number of units of Chinese banks is also noteworthy, which in terms of organization translates to the problem of the effective use of distribution channel for banking services (bank units network management, optimization of bank units networks ${ }^{15}$ ). The five largest banks in China dispose of a total of 65.989 units, whereas the Polish banking sector consists of 639 banks (47 commercial banks, 19 units of credit institutions and 573 cooperative banks) the number of national bank units and bank subsidiaries amounted to $13.956^{16}$ at the end of April 2012.

In the Chinese banking sector one can distinguish the following types of credit institutions: strategic banks, non-state commercial banks, urban commercial banks, state commercial banks, foreign banks, postal bank and rural credit cooperatives. The assets and net profit per employee in each type of credit institutions in China at the end of 2010 are presented in table 3.

\footnotetext{
${ }^{13} \mathrm{http} / / /$ www.gfmag.com

${ }^{14}$ Raport o sytuacji banków w okresie I -IX 2011 r. Warszawa: Urząd Komisji Nadzoru finansowego, 2011 , p. 6.

${ }^{15}$ Kowalczyk, A. Optymalizacja sieci placówek banków w Polsce.Bank i Kredyt, 2004, No. 8.

${ }^{16}$ http://www.knf.gov.pl/danemiesięczne/kwiecień 2012.
} 
Table 3. The assets and profits per employee in each type of credit institutions in China (millions CNY)

\begin{tabular}{|l|c|c|}
\hline \multicolumn{1}{|c|}{ Type of institution } & $\begin{array}{c}\text { Assets per } \\
\text { employee }\end{array}$ & $\begin{array}{c}\text { Net profit per } \\
\text { employee }\end{array}$ \\
\hline Banks strategic & 128,60 & 0,70 \\
\hline Non-state commercial banks & 62,84 & 0,57 \\
\hline City commercial banks & 38,01 & 0,37 \\
\hline National commercial banks & 30,35 & 0,33 \\
\hline Foreign banks & 48,37 & 0,22 \\
\hline Postal Bank & 22,97 & 0,08 \\
\hline Rural credit cooperatives & 11,60 & 0,04 \\
\hline
\end{tabular}

Source: my own elaboration based on Geppert, A. Challenges for the Chinese of banks. Finance Horizons, 2012, p. 31 .

In the case of the Polish banking sector net income per employee in 2011 improved, thanks to both reduced employment in many banks and improvement of their financial results. For example, at the end of 2011, BRE Bank had net profit per employee in the amount of 225.000 zł, PKO BP -152.000 zł, ING Bank -112.000 zł and Kredyt Bank 63.000 zł. The development of credit institutions is determined by the achieved financial results. In China the rate of return from invested capital and total assets in $2007-2010$ is presented in table 4.

Table 4. ROA and ROE ratios in Chinese banking institutions.

\begin{tabular}{|l|r|r|r|r|}
\hline $\begin{array}{l}\text { Type of credit institution } \\
\text { /Year }\end{array}$ & \multicolumn{1}{|c|}{2007} & \multicolumn{2}{|c|}{2008} & \multicolumn{2}{|c|}{2009} & \multicolumn{1}{|c|}{2010} \\
\hline Banking institutions & 0,9 & 1,0 & 0,9 & 1,0 \\
\hline ROA & 16,7 & 17,1 & 16,2 & 17,5 \\
\hline ROE & 0,9 & 1,1 & 1,0 & 1,1 \\
\hline Commercial Banks & 16,7 & 19,5 & 18,0 & 19,2 \\
\hline ROA & 16,5 &
\end{tabular}

Source: China Banking Regulatory Commission, Annual Report 2010, p. 40.

Indicators of profitability on assets and own capitals in 2007 -2010 remain stable, while the difference between profitability of own capitals of banking institutions and commercial banks is around $2 \%$, except for 2007.

In contrast, the net ROE ratios in the Polish banking sector in 2008 -2010 have developed at the level: $20,61 \%, 10,46 \%$ and $12,67 \%^{17}$. That results in conclusion that the influence of the "American crisis" on the results of the banking sector was far greater than in the Chinese banking sector.

The impact of financial crisis on the banking institutions is related not only to the achieved financial results, but also to the size of credits and loans. According to Fitch rating agency credit institution's sensitivity to the financial crisis rises when the growth in credit action over

\footnotetext{
${ }^{17}$ Rozwój systemu finansowego w Polsce w 2010 r. Warszawa: NBP, 2012, p. 98.
} 
2 years is over $15 \%$ per year, and real estate price growth rate is $5 \%$ per year. China has already fulfilled these conditions.

Between 2009 and 2010, Chinese banks granted loans amounting to 17.5 trillion yuan $(2,7$ trillion USD). Credit growth rate in 2008 and 2009 was on average 18.6 percent, which stimulated speculation on the property market. Experts calculated by the Chinese government index of housing prices in 70 major cities in China rose in January 2011 by 6.4 percent, compared to January of the previous year (in April 2010 the index rose by a record 12,8 percent). Asianomics, a Hong Kong research firm, predicts that Chinese banks will have to face the problem of "bad loans" worth up to 400 billion USD. However, Moody's agency expects that Chinese banks will manage to cover potential losses that would be implied by such a crisis ${ }^{18}$.

In comparison with the Chinese banking sector, the Polish one in 2009 -2011 was characterized by the following values of financial assets designated for trading (table 5).

Table 5 Total financial assets designated for trading in the Polish banking sector with foreign units in 2009 -2011 (in zł).

\begin{tabular}{|c|c|c|c|}
\hline Type of asset & 2009 & 2010 & 2011 \\
\hline $\begin{array}{l}\text { Derivative instruments } \\
\text { (assets) }\end{array}$ & 17.588.599.104 & 12.795 .284 .820 & 20.497 .483 .901 \\
\hline Capital instruments & 44.259 .323 & 27.430 .657 & 101.983 .190 \\
\hline Debt securities & 31.411 .331 .081 & 26.929 .630 .706 & 25.752 .593 .593 \\
\hline Other receivables & 55.192 .146 & 13.916 .065 & 13.938 .150 \\
\hline $\begin{array}{l}\text { Financial assets intended } \\
\text { for circulation }\end{array}$ & 49.099.381.654 & 39.766.262.248 & 46.365.998.834 \\
\hline
\end{tabular}

Source: my own elaboration based on: http://www.knf.gov.pl/opracowania/sektor_bankowy/dane_o_rynku/ Dane_miesieczne.html

In 2009 -2010 the value of assets designated for trading decreased by more than 9,3 billion $\mathrm{z}$, but in 2011 there was an increase in relation to 2010 by more than 6,5 billion zl. The value of debt instruments decreased from 31,411,331,081 zł in 2009 to 26,929,630,706 zł in 2010, and in 2011 there was a further decline to the value of $25,752,593,593 \mathrm{zl}$.

\section{Conclusion}

At the end of 1978 the Chinese government decided to begin economic reforms resulting in an average GDP growth in $1978-2011$ of about 9\% GDP annually. In 1978 China's GDP per capita was 148 USD, whereas in 2005 it was 1,7 thousand USD. Since then the Chinese banking sector has grown more than 388 times - at a rate of about 20 percent a year (measured by total assets). At the same time - since the end of 1978 -the American banking system has grown "only" ten times. The moment when China will surpass the United States also in terms of total assets of the banking sector was inevitable. It happened in the middle of 2010 according to data collected at the end of 2009 total assets of the American banking sector amounted to 11,608 billion USD, whereas the Chinese assets amounted to 11,536 billion USD. But data from the end of the third quarter of 2010 showed a distinct advantage of

\footnotetext{
${ }^{18}$ Kozieł, H. Fitch spodziewa się, że kryzys bankowy wybuchnie w Chinach (http://www.parkiet.com/artykul/1027719.html).
} 
China: the American sector had a value of 11,948 billion USD, while the Chinese one amounted to 13,568 billion USD $^{19}$.

The Chinese financial sector is truly in a class of its own if for no other reason that the size of its banking sector. Yet the Chinese stimulus packages of 2009 and 2010 boosted bank lending and further increased the vulnerabilities of the Chinese banking sector. Given the need to rein in lending and the recent policy emphasis on cooling the economy and bringing down inflation, we expect the era of rapid growth in the Chinese banking system to be over.

\section{Literature:}

[1] FUNGÁČOVÁ, Z., KORHONEN, I. Like China, the Chinese banking sector is in a class of its own. BOFIT Discussion Papers, 2011, No. 32. ISBN 978-952-462-727-6, ISSN 14565889.

[2] GEPPERT, A. Wyzwania dla chińskich banków. Horyzonty finansów, 2012.

[3] GRABKE, K., HORVATH, S., SCHARINGER, M., WOLF, J. China auf demWegzurWeltmacht? Wien: RSO, 2008. ISSN 1028-2211.

[4] OSIŃSKI, J. (ed.) Państwa narodowe wobec kryzysu ekonomicznego. Warszawa: Oficyna Wydawnicza SGH , 2010, ISBN 978-83-7378-506-9.

[5] KOWALCZYK, A. Optymalizacja sieci placówek banków w Polsce, Bank i Kredyt, 2004, No. 8. ISSN: 0137-5520.

[6] Kozieł, H. Fitch spodziewa sie, że kryzys bankowy wybuchnie w Chinach,www.pakiet.co

[7] KRUGMAN, P. Wracaja problemy kryzysu gospodarczego. Warszawa: PWN, 2001. ISBN 83-01-13400-3.

[8] MICHALCZYK, W. (ed.) Wybrane problemy gospodarki światowej pierwszej dekady nowego wieku.Wrocław: Wydawnictwo Uniwersytetu Ekonomicznego we Wrocławiu, 2009. ISSN 1899-3192.

[9] MORAWSKI, W. Kronika kryzysów gospodarczych. Warszawa: Wydawnictwo Trio, 2003. ISBN 83-88542-64-8.

[10] MROWIEC, P. O niektórych skutkach kryzysu finansowego dla systemu bankowego. In: Bankowość w dobie kryzysu finansowego a perspektywy rozwoju regionów. T. 1: Banki wobec kryzysu finansowego. Bielsko -Biała: Wyższa Szkoła Bankowości i Finansów, 2009. ISBN 978-83-61310-36-5.

[11] GOSTOMSKI, E. Bankowość międzynarodowa. Wydawnictwo Uniwersytetu Gdańskiego, 2010. ISBN 978-83-7326-715-2.

[12]PAWŁOWSKI, J. Państwo we wczesnej filozofii konfucjańskiej. Warszawa: Wydawnictwo Uniwersytetu Warszawskiego, 2010. ISBN 978-83-235-0771-0.

[13]Raport o sytuacji banków w okresie I -IX 2011 r. Warszawa: Urząd Komisji Nadzoru finansowego, 2011.

[14]Rozwój systemu finansowego w Polsce w 2010 r. Warszawa: NBP, 2012.

\footnotetext{
${ }^{19}$ Geppert, A. Wyzwania dla chińskich banków. Horyzonty finansów, 2012.
} 
JEL G 21

\section{Pawel Mrowiec, PhD}

Associate professor

High School of Finances and Law

ul. Tańskiego 5, 43-382 Bielsko-Biała, Polska

Tel.: +48 785854545

pawel.mrowiec@onet.eu 